\title{
COXEN Score 36
}

National Cancer Institute

\section{Source}

National Cancer Institute. COXEN Score 36. NCI Thesaurus. Code C128233.

A score of 36 on the COXEN Sensitivity Scale. 